\title{
Correspondence of Visual Evoked Potentials with FMRI Signals in Human Visual Cortex
}

Kevin Whittingstall • Doug Wilson •

Matthias Schmidt · Gerhard Stroink

Published online: 7 November 2008

(C) Springer Science+Business Media, LLC 2008

\section{Erratum to: Brain Topogr}

DOI 10.1007/s10548-008-0069-y

This article was published with the given name and family name for each of the four authors in reverse order.
The correct order, given name followed by family name, is shown in this erratum.

The online version of the original article can be found under doi:10.1007/s10548-008-0069-y.

K. Whittingstall $(\bowtie) \cdot$ D. Wilson · G. Stroink Department of Physics, Dalhousie University, Halifax, Canada B3H 3J5

e-mail: kwhittin@fizz.phys.dal.ca

M. Schmidt

Department of Radiology, IWK Health Center, Halifax,

Canada B3H $3 J 5$ 